F. Reprod. Fert. (1967) 13, 67-73

\title{
OVARIAN RESPONSE AND CLEAVAGE RATE OF OVA IN CONTROL AND FSH-PRIMED RABBITS RECEIVING VARYING LEVELS OF LUTEINIZING HORMONE
}

\author{
N. B. VARIAN*, R. R. MAURER AND R. H. FOOTE \\ Department of Animal Husbandry, Cornell University, \\ Ithaca, New York, U.S.A. \\ (Received 10th January 1966, accepted 15th March 1966)
}

\begin{abstract}
Summary. The superovulatory response of Dutch-belted does receiving $0 \cdot 10,0 \cdot 25,0 \cdot 50,1 \cdot 00,2 \cdot 00$ and $4 \cdot 00 \mathrm{mg}$ of $\mathrm{LH} / \mathrm{kg}$ of body weight following priming with twice daily injections of $0.50 \mathrm{mg}$ of FSH each for 3 days was examined. The does were inseminated immediately following LH injection. Rabbits given the lowest level of LH did not ovulate, and an average of 1.0 ovulation points was obtained following the $0.25 \mathrm{mg}$ level of LH. All does receiving $\geqslant 0.50 \mathrm{mg}$ of $\mathrm{LH}$ ovulated, with an average of $33 \cdot 7,40 \cdot 0,45 \cdot 1$ and $35 \cdot 6$ ovulation points for the $0.50,1 \cdot 00,2 \cdot 00$ and $4.00 \mathrm{mg}$ levels, respectively $(P>0 \cdot 10)$. Some large unruptured follicles remained in all groups after they received LH.

The proportion of cleaved ova collected from FsH-primed does 26, 28 and $30 \mathrm{hr}$ after LH administration was 68,86 and $91 \%$ respectively, whereas in non-primed controls all fertilized ova appeared to have cleaved by $26 \mathrm{hr}$. This difference is attributed to the longer time required for ovulation to be completed in FsH-primed animals rather than a delay in cleavage rate following fertilization.
\end{abstract}

\section{INTRODUCTION}

Ovulation or superovulation in rabbits has been induced by a variety of preparations containing gonadotrophins (Pincus, 1940; Parkes, 1943; Warwick, Murphree, Casida \& Meyer, 1943; Adams, 1956; Beatty, 1958; Hafez, 1961; Harper, 1963; Kennelly \& Foote, 1965). Many of these vary considerably in potency and a wide range of dosages has been employed. Stormshak \& Casida (1964) induced ovulation in mature pseudopregnant New Zealand rabbits with as little as $0.010 \mathrm{mg}$ of purified LH, and Hilliard, Archibald \& Sawyer (1963), using pituitary luteinizing hormone (PLH), induced ovulation in nonprimed New Zealand does with $0.06 \mathrm{mg}$ of hormone $/ \mathrm{kg}$ of body weight. With Dutch-belted females $0.5 \mathrm{mg}$ of $\mathrm{LH} / \mathrm{kg}$ of body weight was as effective as 1.0 $\mathrm{mg}$ of $\mathbf{L H} / \mathrm{kg}$ in causing ovulation (Foote, Hafs, Staples, Gregoire \& Bratton, 1963). Kennelly \& Foote (1965) used essentially the higher dose of LH to superovulate FSH-primed immature and mature Dutch-belted does, and obtained

* Present address: Department of Animal Science, Iowa State University, Ames, Iowa, U.S.A. 
a mean response of more than fifty ovulation points. However, several mature follicles always failed to rupture. Wilson \& Zarrow (1962) found that the ovulatory response of PMs-primed mice increased with increasing amounts of HCG or LH to a point where no further increase in response could be achieved. Parkes (1943) reported that 10 i.u. of chorionic gonadotrophin was optimal for rabbits, but the superovulatory response was relatively low.

The present study was undertaken to measure the ovulatory response in FsH-primed rabbits given different levels of $\mathbf{L H}$, so as to establish both the maximum ovulatory response and the minimum dose giving an acceptable response. A second objective was to compare cleavage stages in fertilized ova collected from FSH-primed and control rabbits at corresponding intervals after LH injection, since the work of Kennelly \& Foote (1965) suggested that ovulation may be somewhat prolonged in superovulated animals when compared with those ovulated normally (Harper, 1963).

\section{MATERIALS AND METHODS}

Dutch-belted does in our colony, ranging from 22 to 118 weeks of age, with varying reproductive histories were used. None of the animals had received FSH previously, but some of them had received one or two injections of $\mathbf{L H}$ several months before the present experiment. The does were assigned randomly so that each treatment group contained nine does. Six levels of LH were employed: $0 \cdot 10,0.25,0.50,1.00,2.00$ and $4.00 \mathrm{mg}$ of $\mathrm{LH} / \mathrm{kg}$ of body weight. Initially the four lower levels were studied. Subsequently, it seemed desirable to test higher levels. The 2.00 and $4.00 \mathrm{mg}$ levels were added and the $1.00 \mathrm{mg}$ level repeated. Each LH group was divided into three equal subgroups and killed 26, 28 and $30 \mathrm{hr}$ after injection of LH (PLH Armour). The LH was dissolved in physiological saline and injected intravenously into the marginal ear vein. Before receiving LH, does were primed with $0.50 \mathrm{mg}$ of FSH (FSH-P Armour) injected subcutaneously twice daily for 3 days. The dose and schedule were the same as previously used (Kennelly \& Foote, 1965), but it was unfortunately reported as the dose of $\mathrm{FSH} /$ day instead of per injection given twice daily.

Twenty-six unprimed does from the colony received only $1 \mathrm{mg}$ of $\mathbf{L H}$ and served as controls. These does were killed at intervals, 23 to $33 \mathrm{hr}$ after LH injection, for comparison with the superovulated does.

Additional information on cleavage rate in superovulated does was obtained from thirty-two does, divided into two equal groups receiving either 2.5 or 5.0 $\mathrm{mg} \mathrm{LH} /$ animal (about 1 or $2 \mathrm{mg} / \mathrm{kg}$ ) after FSH priming. These animals were killed at different times 24 to $32 \mathrm{hr}$ following LH injection.

Immediately after the administration of $\mathrm{LH}$ does were inseminated with $0 \cdot 1$ $\mathrm{ml}$ of high quality semen collected from fertile bucks. The semen samples were divided and used randomly across all treatment groups.

Ova usually were flushed towards the uterine end of the oviduct, as described by Kennelly \& Foote (1965), except that hyaluronidase was not used. As a check on this procedure, oviducts on one side in seven animals were flushed first from the uterine end and then from the infundibular end, while the oviduct 
from the other side was flushed twice, but in the reverse order. No additional ova were recovered by flushing from the uterine end after flushing by the usual procedure, but four more ova were obtained by the usual procedure following an initial flushing from the uterine end. Uteri also were flushed whenever a sizeable discrepancy occurred between the number of ovulation points counted and the number of ova recovered from the oviduct. The ovaries were examined with the aid of a dissecting microscope at $10 \times$, and the number of unruptured follicles approximately $2 \mathrm{~mm}$ or more in diameter and the number of ovulations were counted.

The data were analysed statistically according to procedures outlined by Henderson (1959).

TABLE 1

MEAN NUMBER OF OVULATION POINTS, UNRUPTURED FOLLIGLES AND OVA FROM RECOVERED FSH-PRIMED RABBITS

\begin{tabular}{|c|c|c|c|c|c|c|}
\hline $\begin{array}{l}\text { LH dose } \\
(m g / k g)\end{array}$ & $\begin{array}{l}\text { No. of } \\
\text { does }\end{array}$ & $\begin{array}{c}\text { No. } \\
\text { ovulated }\end{array}$ & $\begin{array}{c}\text { Ovulations } \\
\text { /doe }\end{array}$ & $\begin{array}{c}\text { Recovered } \\
\text { ovaldoe }\end{array}$ & $\begin{array}{l}\text { Unruptured } \\
\text { follicles/doe }\end{array}$ & $\begin{array}{l}\% \text { ruptured } \\
\text { follicles }\end{array}$ \\
\hline $\begin{array}{l}0 \cdot 10 \\
0 \cdot 25 \\
0 \cdot 50 \\
1 \cdot 00 \\
2 \cdot 00 \\
4 \cdot 00\end{array}$ & $\begin{array}{r}4 \\
9 \\
9 \\
18 \\
9 \\
9\end{array}$ & $\begin{array}{r}0 \\
4 \\
9 \\
18 \\
9 \\
9\end{array}$ & $\begin{array}{c}0 \\
1.0 \\
33 \cdot 7 \\
40 \cdot 0 \\
45 \cdot 1 \\
35 \cdot 6\end{array}$ & $\begin{array}{c}0 \\
1.0 \\
29 \cdot 0 \\
32.7 \\
36 \cdot 8 \\
31.3\end{array}$ & $\begin{array}{r}45-5 \\
57 \cdot 3 \\
21 \cdot 2 \\
12 \cdot 3 \\
9 \cdot 8 \\
12 \cdot 7\end{array}$ & $\begin{array}{r}0.0 \\
1.7 \\
61.4 \\
76.5 \\
82.1 \\
73.7\end{array}$ \\
\hline
\end{tabular}

\section{RESULTS}

The number of ovulations and the number of unruptured follicles observed in the group of Dutch does given six levels of $\mathbf{L H}$ are summarized in Table 1. The $0.10 \mathrm{mg} / \mathrm{kg}$ level of $\mathrm{LH}$ was discontinued after it produced no ovulatory response in four primed animals and a poor response was obtained at the next higher level of $\mathrm{LH}$. The mean number of ovulations increased up to the $2.00 \mathrm{mg}$ level, although the differences in response between the 0.50, 1.00, 2.00 and 4.00 $\mathrm{mg}$ levels were not statistically significant $(P>0 \cdot 05)$. This plateau effect was observed by Wilson \& Zarrow (1962) in rats and mice. As the number of ovulations increased the number of unruptured follicles showed a corresponding decrease, but some unruptured follicles always remained. This relationship is shown graphically in Text-fig. 1. The number of ovulations plus unruptured follicles was similar in all groups.

Occasionally a few corpora lutea were observed which appeared to be slightly older than the rest of the ovulation points. They were similar to those observed by Kennelly \& Foote (1965) in FsH-primed does laparotomized before LH administration, and were presumably induced by the preceding FSH injections.

The extent of cleavage of ova recovered from the oviducts is shown in Table 2. The proportion of ova cleaved 26,28 and $30 \mathrm{hr}$ after $\mathrm{LH}$ injection was 38, 86 and $91 \%$. This suggests that at least $30 \mathrm{hr}$ should elapse after LH injection of FsH-primed rabbits if cleavage is to be used as a criterion of fertilization. The 
percentage recovery of the ova was $78 \% 26 \mathrm{hr}$ after $\mathrm{LH}$ injection and $86 \%$ $30 \mathrm{hr}$ after $\mathrm{LH}$ injection.

Data in Table 2 on the forty-three FsH-primed does which ovulated have

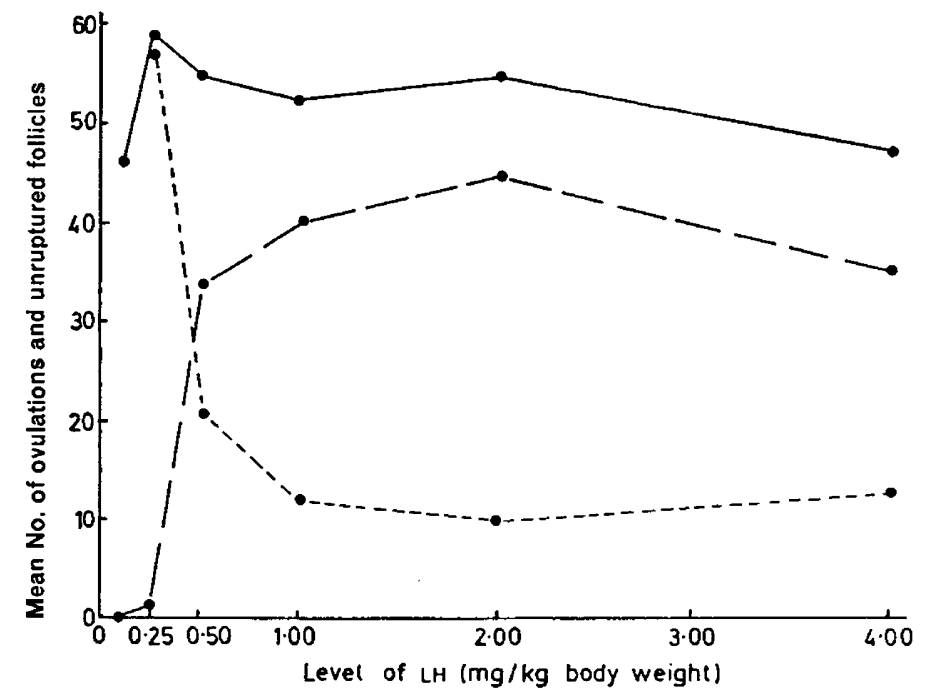

TEXT-FIG. 1. Relationship between the level of $\mathbf{L H}$ administered to FSH-primed does and the number of ovulations and unruptured follicles. tured follicles; - - ovulation points; - - - , unruptured follicles.

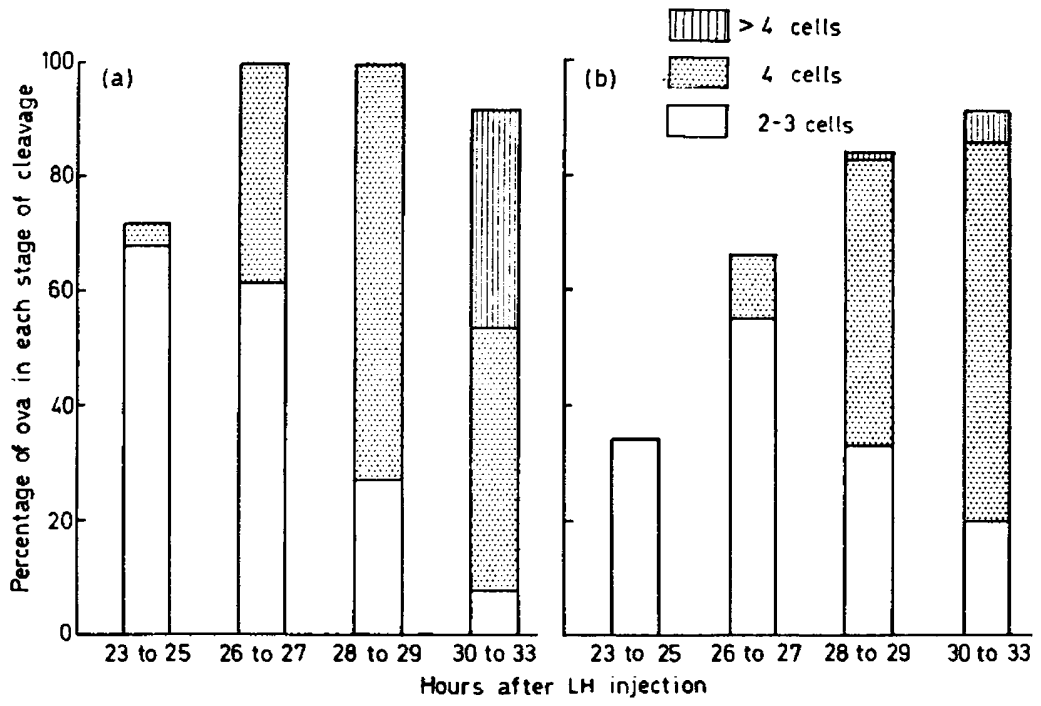

TExT-FIG. 2. Cleavage stages of ova recovered from FsH-primed (b) and non-primed (a) inseminated rabbits at varying intervals after injection of $\mathrm{LH}$.

been combined with the thirty-two other FSH-primed and LH-treated does available, and compared in Text-fig. 2 with the twenty-six controls receiving only LH. The number of ova produced by the control does killed after 23 to 25, 26 to 27,28 to 29 and 30 to $33 \mathrm{hr}$ were 104, 40, 23 and 50 respectively, while 


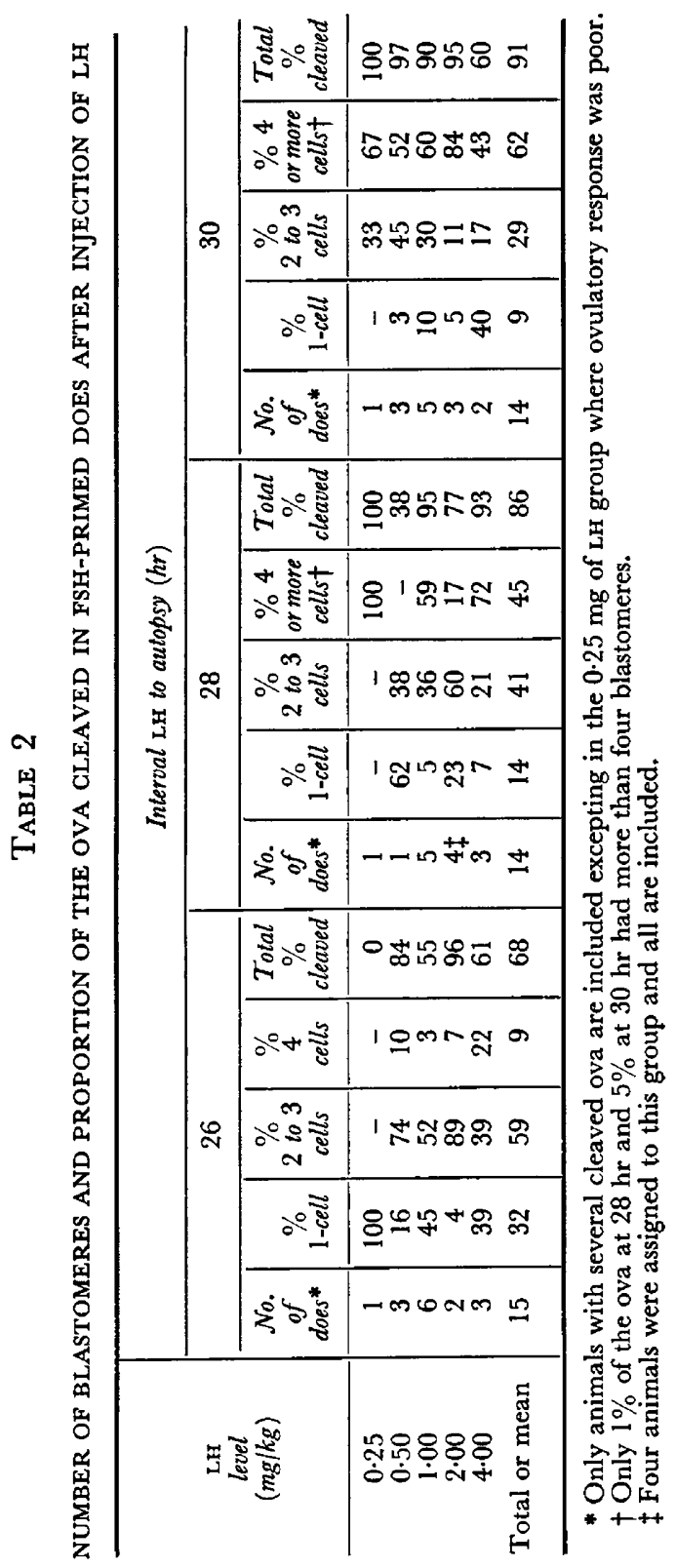


the corresponding numbers for the seventy-five FsH-primed does were 231, 1268, 926 and 739. Text-fig. 2 shows that, at each interval, a higher proportion of the ova from the non-primed rabbits was in a more advanced stage of development than those from the FsH-primed does.

Ovarian weights obtained for the groups receiving $0 \cdot 25,0 \cdot 50,1 \cdot 00,2 \cdot 00$ and $4.00 \mathrm{mg}$ of $\mathrm{LH} / \mathrm{kg}$ of body weight were $478,729,749,788$ and $900 \mathrm{mg}$, respectively. While the weights tended to parallel the level of LH injected, the differences were not statistically significant $(P>0 \cdot 10)$. There was no gross difference in the appearance of the ovaries recovered from does receiving the different levels of $\mathrm{LH}$.

Pituitary weights obtained for six animals/group in the $1.00,2.00$ and 4.00 $\mathrm{mg}$ of $\mathrm{LH}_{\mathrm{H}}$ groups averaged $32 \cdot 0,33 \cdot 6$ and $40 \cdot 8 \mathrm{mg}(P>0 \cdot 10)$.

\section{DISCUSSION}

The minimal dose for consistently ovulating FSH-primed mature Dutch-belted rabbits was $0.50 \mathrm{mg}$ of $\mathrm{LH} / \mathrm{kg}$ of body weight (Table 1 ). This is considerably more than the amount of a similar Armour LH required for non-primed mature New Zealand does (Hilliard, Archibald \& Sawyer, 1963) or more than the amount of highly purified LH required to ovulate pseudopregnant New Zealand does (Stormshak \& Casida, 1964). These results suggest that there may be a breed difference in the level of $\mathbf{L H}$ required to induce ovulation and/or a probable increase in LH required following priming with FSH.

All forty-five animals receiving $0.50 \mathrm{mg}$ or more of $\mathrm{LH} / \mathrm{kg}$ of body weight ovulated, and the mean number of ovulations exceeded most of the reports in the literature. While this mean tended to increase as the LH level was increased to $2.0 \mathrm{mg} / \mathrm{kg}$ of body weight, the non-significant differences $(P>0 \cdot 10)$ suggest that the $0.50 \mathrm{mg}$ level is not only satisfactory but might be preferable where repeated injections are used to minimize a possible anti-hormone response.

Although the ovulatory response at the $4.0 \mathrm{mg}$ level of $\mathrm{LH}$ was not significantly lower than at the 2.0 level, earlier work (Foster, Foster \& Hisaw, 1937; Foster \& Fevold, 1938) suggests that high levels of LH may be less conducive to ovulation. Wilson \& Zarrow (1962) also observed a slight downward trend in ovulatory response when high levels of HCG were given to rats and mice.

Since a wide range of ages was represented the rabbits receiving the four higher levels of LH were classified by age. Within the range studied there was no relationship between age and ovulatory response; Beatty (1958) has reported a negative relationship between these two variables in rabbits covering a much greater age span. Individual does varied greatly in response. Always there were some unruptured large follicles, even in ovaries showing excellent ovulatory response. Thus, high levels of LH appear to be incapable of causing complete rupture of all large follicles. It is conceivable that some of these follicles were developing when the LH was injected and that a subsequent injection might have caused additional ovulations.

The proportion of cleaved ova collected from superovulated does continued to increase from 26 to $30 \mathrm{hr}$ after $\mathrm{LH}$ administration (Table 2). This is in contrast to the results obtained with non-primed does in which virtually $100 \%$ cleavage 
of the ova was observed $26 \mathrm{hr}$ after LH injection. Text-fig. 2 shows that, at all times studied, more of the ova from the control does were in a later stage of cleavage than were ova from superovulated does. The time lag for this latter group was about 2 to $4 \mathrm{hr}$. This difference is believed to result from the longer time required for some ova to be ovulated in superovulated animals (Kennelly \& Foote, 1965), rather than a delay in the development of the fertilized ova. Thus, the first ova shed in the FsH-primed does reach the same stage of development as those in the non-primed does at corresponding intervals, but the larger number of ova shed later in superovulated does not only accounts for the lag but decreases this initial number cleaved when expressed as a percentage of the total.

Any ova shed relatively late might have had less chance of becoming fertilized in our experiments, in which insemination accompanied $\mathbf{L H}$ administration. This might partially explain the tendency to obtain slightly lower cleavage rates in superovulated does.

\section{ACKNOWLEDGMENTS}

This investigation was supported in part by Public Health Service Research Grant GM10263 from the National Institute of General Medical Sciences. The authors are grateful to Carol Somers for technical assistance.

\section{REFERENCES}

Adams, C. E. (1956) A study of fertilization in the rabbit: the effect of post-coital ligation of the fallopian tube or uterine horn. F. Endocr. 13, 296.

BeAtry, R. A. (1958) Variation in the number of corpora lutea and in the number and size of 6-day blastocysts in rabbits subjected to superovulation treatment. F. Endocr. 17, 248.

Foote, R. H., Hafs, H. D., Staples, R. E., Gregoire, A. T. \& Bratton, R. W. (1963) Ovulation rates and litter sizes in sexually receptive and nonreceptive artificially inseminated rabbits given varying dosages of luteinizing hormone. 7. Reprod. Fert. 5, 59.

Foster, M. A. \& Fevold, H. L. (1938) The interrelationship of the pituitary gonadotropic hormones in follicular development and ovulation in the juvenile rabbit. Am. J. Physiol. 121, 625.

Foster, M. A., Foster, R. G. \& Hisaw, F. L. (1937) The interrelationship of the pituitary sex hormones in ovulation, corpus luteum formation and corpus luteum secretion in the hypophysectomized rabbit. Endocrinology, 21, 249.

Hafez, E. S. E. (1961) Procedures and problems of manipulation, selection, storage and transfer of mammalian ova. Cornell Vet. 41, 299.

HARPER, M. J. K. (1963) Ovulation in the rabbit: the time of follicular rupture and expulsion of the eggs, in relation to injection of luteinizing hormone. F. Endocr. 26, 307.

Henderson, C. R. (1959) Design and analysis of animal husbandry experiments. Techniques and Procedures in Animal Production Research. American Society for Animal Production, Beltsville.

Hilliard, J., Archibald, D. \& Sawyer, C. H. (1963) Gonadotropic activation of preovulatory synthesis and release of progestin in the rabbit. Endocrinology, 72, 59.

Kennelly, J. J. \& Foote, R. H. (1965) Superovulatory response of pre- and post-pubertal rabbits to commercially available gonadotrophins. F. Reprod. Fert. 9, 177.

PARKES, A. S. (1943) Induction of superovulation and superfecundation in rabbits. F. Endocr. 3, 268.

PINcus, G. (1940) Superovulation in rabbits. Anat. Rec. 77, 1.

Stormshak, F. \& Gasida, L. E. (1964) Effects of gonadotropins on corpora lutea of pseudopregnant rabbits. Endocrinology, 75, 321.

Warwick, E. J., Murphree, R. L., Casida, L. E. \& Meyer, R. K. (1943) Maintenance of the pregnancy induced in the female rabbit following treatment with pituitary gonadotropins. Anat. Rec. 87, 279.

WiLson, E. D. \& ZARRow, M. X. (1962) Comparison of superovulation in the immature mouse and rat. J. Reprod. Fert. 3, 148. 